\title{
Motivation and Labour Turnover in the Health Sector: Perception of Healthcare Professionals at the Dunkwa-on-Offin Government Hospital, Central Region, Ghana
}

\author{
Michael Ayikwei Quarshie ${ }^{1}$ \\ Alfred Attafuah ${ }^{2}$ (iD \\ Gifty Sarfos $^{3}$ (D)
}

'Department of Entrepreneurship and Business Sciences, University of Energy and Natural Resources, Sunyani, Bono Region, Ghana.

Email:michael.quarshie@uenr.edu.ghTel:00233244628502

Directorate of Human Resource, University of Cape Coast, Cape Coast, Central Region, Ghana.

Email:alfred.attafuah@ucc.edu.gh Tel:00233244665368

${ }^{9}$ Institute for Educational Planning and Administration, University of Cape Coast, Cape Coast, Central Region, Ghana.

Email:giftyasquarshie@gmail.com Tel:00233243136811

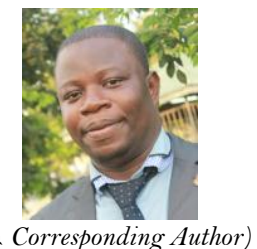

\begin{abstract}
This study aimed at evaluating the impact of motivation on labour turnover among healthcare professionals at the Dunkwa-On-Offin Government Hospital, Central Region, Ghana. The study reviewed literature on organisational equilibrium theory, compensation theory and Herzberg twofactor theory to establish the link between staff motivation and labour turnover. The descriptive cross-section survey was adopted for this study. Questionnaires were employed to obtain data from 165 healthcare professionals at the Dunkwa-On-Offin government hospital using the simple random sampling technique. Data were presented and analyzed using regression and descriptive statistics. The study revealed that most healthcare professionals at the Dunkwa-On-Offin government hospital are fairly satisfied with their work. This is because they are fairly motivated for the services they render at the hospital. The study further established that employee recognition $(\beta=-0.476 ; p$-value $=0.004)$ and working environment $(\beta=-0.319$; $p$-value $=0.015)$ have a significant impact on labour turnover at the government hospital. It was therefore recommended that management of the hospital should maintain credibility in the implementation of its motivational practices to enhance staff satisfaction and retention.
\end{abstract}

Keywords: Motivation, Labour turnover, Working environment, Healthcare professionals, Recognition, Work content, Payment, Promotion.

JEL Classification: $\mathrm{O} 15$

Citation | Michael Ayikwei Quarshie; Alfred Attafuah; Gifty Sarfo (2020) Motivation and Labour Turnover in the Health Sector: Perception of Healthcare Professionals at the Dunkwa-on-Offin Government Hospital, Central Region, Ghana. Asian Journal of Social Sciences and Management Studies, 7(2): 104-113.

History:

Received: 7 February 2020

Revised: 18 March 2020

Accepted: 20 April 2020

Accepted: 20 April 2020

Licensed: This work is licensed under a Creative Commons Attribution 3.0 License $(\mathrm{ccc})$

Publisher: Asian Online Journal Publishing Group
Acknowledgement: All authors contributed to the conception and design of the study.

Funding: This study received no specific financial support.

Competing Interests: The authors declare that they have no conflict of interests.

Transparency: The authors confirm that the manuscript is an honest, accurate, and transparent account of the study was reported; that no vital features of the study have been omitted; and that any discrepancies from the study as planned have been explained.

Ethical: This study follows all ethical practices during writing.

\section{Contents}

1. Introduction

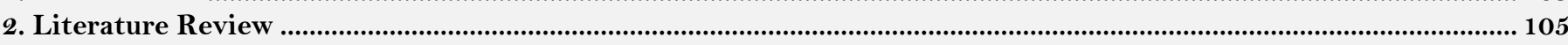

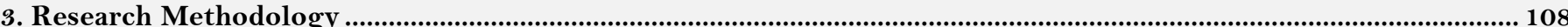

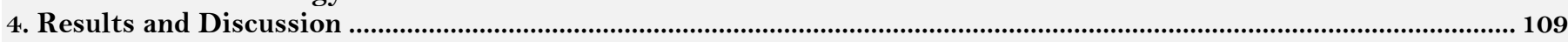

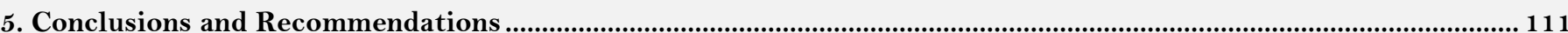

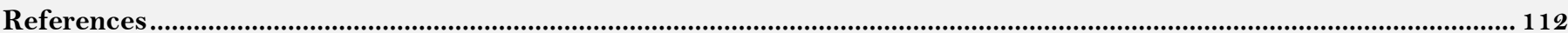




\section{Contribution of this paper to the literature}

The outcome of this study contributes to the literature as it provides useful information on motivation to policymakers, planners and other stakeholders. The study will rebound to the benefit of hospital managers and administrators considering the role that healthcare professional play in delivering healthcare services. A better knowledge of factors that impact on labour turnover was needed to inform district health managers and administrators who are essential at the operational level of health systems and important drivers for performance outcomes in their districts.

\section{Introduction}

Guaranteeing access to quality healthcare service greatly relies upon the hospital's capacity to retain its qualified healthcare professionals (Adjei-Appiah, 2008). For that matter, high nurse turnover is regarded to have negative consequences on healthcare institutions ability to meet patient needs and provide quality care (Shields \& Ward, 2001). Researchers like Saratoga Institute and Kepner-Tregoe (1999) and Hay Group (2001) asserted that employee's turnover in the health sector is mostly costly; reduces the effectiveness and efficiency of an organization and further reduces the quality of health care delivery. Accessible data demonstrates that there is a high rate of employee turnover among healthcare professionals in Ghana (Adjei-Appiah, 2008). For instance, between the periods 1993 and 2002, the Ministry of Health indicated that Ghana lost close to 630 medical doctors, 410 pharmacists and approximately 11,300 nurses to other sectors of the economy or other countries (Ministry of Health, 2002). The Ministry of Health (2002) reported that the country required the services of about 3,000 medical doctors at the various health institutions around the country but had only 964 medical doctors. This situation leads to a deficit of about 2,036 (Ministry of Health, 2002). According to the Ministry of Health (2002), records show that the national doctor-patient ratio in the country for the year 2000 was 1:12,000 and in 2002, it expanded to 1:15,000. For Adjei-Appiah (2008) the high turnover rates for health care practitioners require the Government, and all health sector stakeholders of Ghana to spend scarce resources for recruiting and training, of doctors and nurses, leaving considerably fewer resources for more direct aspects of health care delivery in the country. Hence any health service organisation must assess how it is faring with other employers in this competitive job market Mobley (1982). Meanwhile, the Government of Ghana is the major employer of healthcare practitioners and trend is that if healthcare professionals decide to leave the government hospitals, majority of them travel out of the country while a few get employed in private hospitals (Arkoh, 2004).

According to Adjei-Appiah (2008) most healthcare researchers in Ghana claim that the problem of retaining healthcare workers is primarily related to the working environment, job satisfaction and conditions of service. As a result, governments over the years have periodically engaged healthcare professionals by using many forms of inducements and incentives. It, however, appears that these initiatives have not yielded any significant impact on reducing the high degree of labour turnover in the health sector. Owing to this and many more, numerous health care policies including the National Health Insurance Scheme (NHIS) run into many challenges (Ministry of Health., 2016). The Government of Ghana upon recommendations made by professional health care bodies such as the Ghana Medical Association (GMA) and Ghana Registered Nurses Association (GRNA) in the year 2001 prompted the government to release about five million dollars in the year 2003 onwards into a healthcare revolving fund. The fund was meant for the improvement in infrastructure, purchase of cars for the various health professionals, salaries enhancement, payment of extra duty allowances and also agreed in principle to provide a private housing scheme and to make it possible for them to own an accommodation (Adjei-Appiah, 2008; Ministry of Health., 2016).

Despite frantic efforts by government, healthcare professionals continue to express dissatisfaction with continuous attrition of their members. Some studies (Adjei-Appiah, 2008; Arkoh, 2004; Numerof, Abrams, \& Shank, 2002) have demonstrated that the healthcare sector has one of the most noteworthy turnover rates. The DunkwaOn-Offin government hospital is the largest and highly equipped hospital in Dunkwa and its suburbs. The hospital employs and accommodates diverse healthcare professionals but is bedevilled with high labour turnover in recent times. The claim is that attention given to the improvement of remuneration and working conditions seems to be woefully insufficient (Arkoh, 2004; Ministry of Health., 2016). Moreover, analysis of the literature reveals that not much research has been done on motivation and labour turnover in the health sector within the Ghanaian context to verify these claims or otherwise. Most of the studies conducted on motivation and labour turnover mainly focus on the education and hospitality sectors (Agyei-Ohemeng \& Sedegah, 2018; Kosi, Sulemana, Boateng, \& Mensah, 2015; Sam, Effah, \& Osei-Owusu, 2014). Owing to these and many more, this study sought to assess healthcare professionals' perception of motivation and the impact of motivational factors on labour turnover at the DunkwaOn-Offin government hospital.

\section{Literature Review}

\subsection{Theoretical Review}

The major sociological theories used to explain employees' motivation and labour turnover are the theory of organisational equilibrium, compensation theory and Herzberg theory. These theories were chosen because they are appropriate for discussing the relationship between motivation and labour turnover. The section that follows examines the theories' general arguments, assumptions and how they relate to motivation and labour turnover.

\subsection{Theory of Organisational Equilibrium}

This theory proposes that desirability of movement and the ease of movement are the two main drivers of employee turnover. The desirability of movement depicts the individual's satisfaction with the job, whereas ease of movement generally reflects perceived or actual job alternatives in the external market. Job satisfaction and lack of alternatives are two important factors in employees' decisions to stay in an organisation (March \& Simon, 1958). This study is therefore interested in assessing whether or not the healthcare professionals at Dunkwa-On-Offin 
government hospital are satisfied with their job, whether or not there are real or perceived job alternatives in the labour market and to evaluate the impact of motivation on labour turnover at Dunkwa-On-Offin government hospital.

\subsection{Compensation Theory}

Among the underlying foundations of compensation theory is that compensation influences behaviour. The premise emanated from the study of behaviour psychologists, thus B.F. Skinner, who trusted in operant moulding (Kohn, 1996). Skinner illustrated that if you reward an organism for certain behaviour, that organism will be more likely to repeat that behaviour. Converted into organizational terms, if you reward an employee for exhibiting good behaviours of producing results, that employee will probably rehash those same activities. It is critical to note that there is a small number of individuals that do not buy into these principles (Kohn, 1996). The faction argues that human behaviour is much too complex to be controlled and manipulated through reward programmes. Their argument emphasizes the need to fully appreciate the role of compensation as a tool for achieving employee satisfaction and retention. It is particularly important for an institution to fully appreciate the effect of its compensation system (Noe, Hollenbeck, Gerhart, \& Wright, 2003). Compensation can substantially promote an organization's success and satisfy employee career objectives. It has been underscored that remuneration should likewise be designed legitimately as though not watchful amid design and implementation. Compensation systems can accidentally fail to inspire the desired behaviour (e.g. inadequate compensation plan) or worse, motivate undesired conduct (e.g. individualistic behaviour in a team environment) (Lawler, 1996).

\subsection{Herzberg Two-Factor Theory}

Amedzo (2007) discussed Herzberg's motivation-hygiene theory by distinguishing motivational and maintenance factors in work circumstances. The theory endeavours to clarify satisfaction and motivation in an organisation by expressing that satisfaction and dissatisfaction are driven by various variables (that is motivation and hygiene factors). A research study was made by Herzberg and his associates based on the interview of 200 engineers and accountants who worked in eleven unique firms in Pittsburgh territory. Based on this study, two occupation factors were recognized, namely motivators or satisfiers and hygiene or maintenance factors. Motivators are those parts of the work that make individuals want to perform and inform their choice to remain or quit an organisation. These motivators are viewed as intrinsic to the content of the work and include variables such as achievement, recognition, advancement, work itself, the possibility of growth and responsibility.

Conversely, dissatisfying encounters, labelled "hygiene" factors, to a great extent results from extrinsic, nonwork related factors, for example, organization policies and administration, salary, technical supervisory style, interpersonal relationship with supervisors, interpersonal relationship with peers and interpersonal relationship with subordinates, salary and job security. Herzberg, Mausner, and Sayderman (1957) have reported on the motivational variables which are responsible for employees' job satisfaction and eventual retention in an organisation. The theory explains employee satisfaction as being driven by motivation and hygiene factors or intrinsic and extrinsic factors. Motivators are those part of the job that make individuals want to perform and inform their choice to remain or quit an organisation. Chiboiwa, Samuel, and Chipunza (2010) define intrinsic motivators as factors that are inside a person and are based on individual needs. They include accomplishment, acknowledgement, the job itself, obligation, and prospects for career growth. Conversely, the authors define extrinsic factors as hygiene factors that are required for employee satisfaction but are not directly related to the nature of the job. They include company policies, salary, status, job security, and supervisory styles. The theory, thus, suggests that employees see themselves and how they are dealt with regarding their surrounding environment, work systems not in isolation thus they should be managed and treated likewise. The charge along these lines for an organisation is to create reward systems that are seen to be reasonable, impartial and distribute the reward as per worker convictions in the organisation.

\subsection{Meaning of Turnover}

Turnover can be explained as the movement of labour out of and into a working organization (Lashley, 2000). Another definition may be simply stated as to when an employee leaves an organization for whatever reason(s). Turnover can take several forms. It can be intended or unintended, purposeful or dysfunctional, preventable or unavoidable. In a voluntary turnover, an employee leaves the organization of his own free choice with some of the possible reasons being: low salary, job dissatisfaction or better job opportunities elsewhere whereas involuntary turnover takes effect when the organization decides to remove an employee due to poor performance or economic crisis (Aksu, 2004). Besides, Price (1977) said that voluntary turnover can be termed as avoidable turnover and involuntary turnover as unavoidable turnover. However, a study by Wright (1993) focused on intended rather than unintended turnover which concludes that voluntary turnover is a critical issue for both employees and organizations.

\subsection{Conceptual Models of Employee Turnover}

One of the earliest and perhaps most influential integrative models of employee turnover was introduced by March and Simon (1958). They studied turnover factors affecting perceived desirability and affluence of movement within the labour force. Subsequently, the study of turnover in various contexts and the development of turnover models has burgeoned (McBey \& Karakowsky, 2001; Mobley, 1982). As early as 1977, Price (1977) published an extensive review and codification of the turnover literature. He presented the determinants and prevailing variables associated with turnover. Price (1977) viewed the principal determinants of turnover as pay level, integration, instrumental communication, formal communication and centralization. In the same year, Mobley (1977) developed intermediate linkages that threw more light on some vital sources of influence. Mobley model focuses on turnover as a process and questions the role of satisfaction as the immediate precursor of turnover. Then, in 1979, Mobley expanded his model of the labour turnover process. The amended model suggests that there are four primary determinants of intentions to quit and subsequently result in turnover: job satisfaction-dissatisfaction; positive 
expectation about a future role in the organization; expectation of finding an attractive job external to the present organization and non-work values and contingencies.

In 1982, Mobley again produced a simplified model of turnover determinants. He used the term "determinants" in a generic sense to describe any variable potentially related to turnover which could be direct, indirect, causal or co-relational. The determinants identified were organizational variables, external economy, individual non-work and work-related variables. In 1984, Jackofsky further added to literature with his integrated process model of turnover. He reviewed previous research on labour turnover and integrated job performance in the process of turnover. McBey and Karakowsky (2001) affirmed that regardless of which turnover model is considered, much of the studies have drawn attention to four sources of influence on turnover. The four influences highlighted are; work-related attitudes (push factors), external environment factors (pull factors), individual characteristic factors, and Job performance factors. This turnover model has continued to shape the thinking of the turnover literature in recent times. It can thus be seen that the causes and correlation of employee turnover have been studied from many different perspectives. Most researchers have linked some variables to turnover. A study by Morrow, McElroy, Laczniak, and Fenton (1999) has established a positive association between absenteeism and voluntary turnover and a negative association between job performance and turnover. Among the probable causes of turnover, remuneration was often cited as the reason for leaving an organisation (Hinkin \& Tracey, 2000; Rowley \& Purcell, 2001).

\subsection{Consequences of Turnover}

The impact of turnover can be either positive or negative, or both for an organization. According to Carbery, Garavan, O'Brien, and McDonnell (2003) from the perspective of the employer, turnover is viewed as a negative situation and from the view of the employee, it is often seen more positively. For the employer, perhaps the most obvious positive organizational consequences are the potential replacement of a former employee with one who is better. In terms of negative impact, from a managerial perspective, it would seem apparent that the organizational consequences of turnover are closely associated with the additional cost of recruitment and training and potentially lower profitability. According to Mobley (1982) the most frequently studied organizational influence of turnover, both direct and indirect is the monetary cost which can vary substantially between and within organizations. Some researchers (Aksu, 2004; Hinkin \& Tracey, 2000; Kaak, Field, Giles, \& Norris, 1998) found that high turnover rates have adverse effects on the profitability of organizations. Turnover is expensive. It affects organizational profitability because in measuring turnover three major costs are included, namely; separation cost, replacement cost and training cost (Mobley, 1982). Johnson (1981) viewed turnover as challenging for the industries, affecting the quality of services and products, and suffering considerable replacement cost and recruitment costs. Johnson further avers that labour turnover acts as a hindrance to increased effectiveness and efficiency, a view maintained in more recent literature. For example, the issue of quality cannot be ignored when dealing with employee turnover. It is often said that the people who leave are those who are most talented (Hinkin \& Tracey, 2000).

The issue of quality is highlighted when someone unfamiliar with the tasks takes on the vacant position. It takes a long time to learn a new job and ranges from 54 to 80 days to reach an acceptable level of competence (Hinkin \& Tracey, 2000). Contrarily, a positive impact could be seen for an employee who quits a job feeling motivated by expectations of greater net positive consequences in a new post (Mobley, 1982). This may be in the form of higher rates of pay or career development. However, the negative consequences of turnover also exist for employees who misjudge the organizations that they are about to join. Unrealistic expectations of the new organization, for example, about better benefits or working conditions may lead to a negative impact. Other possible negative consequences may involve loss of seniority, co-workers or boss (Mobley, 1982). Also, there are costs (financial, social and psychological) of moving to a new post that has to be borne regardless of any increase in salary or seniority.

\subsection{Possible Causes of Employee Turnover}

Stressors can be referred to as job or organizational conditions that may threaten an individual's well-being. Stressors are the element of stress. Stranks (2005) stated that the causes of stress are diverse but it normally includes three aspects that are environmental, occupational and social. Some researchers have studied workplace stressors in a variety of industries. Workplace stress which includes role conflict, role overload and role ambiguity has been discussed in comprehensive reviews in the occupational stress literature. According to Jex (1998), a role can be seen as a set of behaviours that are expected of an individual occupying a certain position. In social systems such as organizations, role plays an important part in coordinating an individual's behaviour. Every organization needs roles to function effectively as employees in an organization received role-related information through both formal and informal sources (Jex, 1998). Cooper and Marshall (1978) noted that role ambiguity exists when a person has insufficient information about work role and where there is lack of clarity about the work objectives associated with the role, about colleague's expectation of the work role and the scope and responsibilities of the job. Ideally, in most cases, workplace role-related information should be communicated to employees and it should be consistent. If the role-information is not clear to the employee, this situation may lead to role ambiguity. Jex (1998) further explained that role ambiguity may occur for several reasons. First, it is from the organizational perspective where poorly written job descriptions and monitoring exist.

Second, some roles are simply more difficult to define and this causes employees to have difficulty in understanding the role. This mostly happens for managerial positions. For instance, in some organizations, managers are expected to achieve a certain level of sales but due to little guidance and lack of experience, this is not achievable. Environmental change is identified as the third common cause of role ambiguity. This happens when the content of many organizational roles is linked to factors and events outside the organization. Also, role ambiguity happens to employees who have a complex description or where a job requires multi-tasking. To avoid job ambiguity, an employee has to acquire multiple skills to perform all related tasks. Above all, Kahn., Wolfe, Quinn, and Snoek (1964), in their study, found that men who suffered from role ambiguity experience lower job satisfaction, high job-related tension, greater senses of futility and lower self-confidence. This implies the 
importance of clear role definitions at the workplace to avoid unintentional consequences to employees. Role conflict occurs in a situation where an individual has different expectations of roles to those of higher management or other stakeholders as to the performance of a given task. Sigler (1988) stated that when an individual holds various overlapping roles or the behaviour expected is inconsistent, this can cause role conflict. Kahn. et al. (1964) found that men who suffered more work conflict had lower job satisfaction and higher job-related tension. Thus, it is suggested that role conflict increases job dissatisfaction and in turn, increases quitting the behaviour. With regards to role overload, Cooper., Dewe, and O'Driscoll (2001) refer to the sheer amount of effort required for a role to be completed. It happens when a worker has been pressurized to do more and finish the work within a normal workday hour (Glazer \& Beehr, 2005). Role overload is one of several factors that can impact on job satisfaction. According to Galinsky, Kim, and Bond (2001) about two-thirds of managers and professional employees and one-third of other employees felt overworked. They further stressed that one reason for work overload is customer expectation. The consequences of work overload include reduced job satisfaction, which ultimately leads to turnover behaviour. Work overload also causes errors in products and services.

\subsection{Stress as a Cause of Employee Turnover}

Stress is a term that can be viewed differently by different people and there is no single definition of the term (Stranks, 2005). Ivancevich and Ganster (1987) agreed that there is no particular definition that has been generally accepted as the final view of what stress entails. Law, Pearce, and Woods (1995) stated four criteria that can be useful in demonstrating stress. They believe that: 1) stress can be positive and negative; 2) stress can be caused by a wide variety of things; 3) it is not so much the event but human reaction to the event which causes stress and 4 ) stress is a demand made on our capacities and it is these capacities which determine our response to the demand. In the case of employees at work, they would worry potentially about many things such as too much or too little work, inefficient management, excessive working hours, job security, and pressure on or conflict with job demands (Stranks, 2005). These sorts of things can result in stress in the workplace. A 1992 UN report called job stress "The 2oth Century Epidemic" and the World Health Organization called stress a "World Wide Epidemic". Stress in the workplace also happens in the health sector. The examples of stress observed are derived mainly from job overload such as understaffing, temporary staff shortages, unrealistic task criteria and also bullying (Rowley \& Purcell, 2001).

Even though research on stress has been an extremely active field for many years, job stress in the health sector has not been widely investigated (Zohar, 1994). According to Agyemang, Nyanyofio, and Gyamfi (2014) stress creates a mental, physical, social, and economic response that needs adjustment to neutralize pressure. Job stress occurs during the time of work due to contact between the workers. Job stress can occur when workers are unable to cope with labour demand which further creates psychological stresses (Nowrouzi et al., 2015). Job stress is a concern for both workers and the organisations at large. if job stress is poorly handled, it can adversely affect the organization's survival and growth. Job stress would also hinder the organisation's recruiting and retention of skilled staff. $\mathrm{Hu}, \mathrm{Wang}, \mathrm{Xu}$, and $\mathrm{Xu}$ (2014) study reported that medical employees have a high level of stress which is a common phenomenon among healthcare professionals. Work stress in the healthcare sector is critical because if it is not managed well it tends to impact negatively on the quality of work. Healthcare professionals, such as the doctor, nurse, and other supporting staff who work in the hospital are exposed to stress. If stress is not adequately managed could affect not only the staff but also the patients (Pisljar, Lippe, \& Dulk, 2011). Besides work demand, patients can also be exposed to negative emotions from healthcare professionals who work at the hospital. Emotional contagion is likely to occur if workers frequently interact with people who suffer depression as a result of the disease they have (Pisljar et al., 2011).

\subsection{Work Environment}

The work environment is one of the factors that affect an employee's decision to stay with an organisation (Bültmann et al., 2005). Ramlall (2003) associates the work environment with a focus on physical aspects such as heavy lifts, noise, and exposure to toxic substances. Miller, Erickson, and Yust (2001) opined that workers benefit from a positive work environment that provides a sense of belonging. Emotional and mental wellness is important to good retention and other indicators of business performance. Levi (2002) advocates that there is a need for organisations to recognise the emerging needs of individuals to keep them committed and provide better jobs with a great work environment to retain employees. Potential remedies to poor workplace health may come from other retention factors like vacation benefits, flexible time, a good work-life balance, effective and open communications, and job enrichment (Wells \& Thelen, 2002). Zeytinoglu and Denton (2006) explain that workplace safety, and health and wellness initiatives can make a fundamental contribution to business performance as well as the improved health and well-being of individual employees. Hytter (2008) has reported that people enjoy working, and strive to work in an organisations that provide a conducive work environment where employees feel they make a difference.

\section{Research Methodology}

This study adopted descriptive cross survey design. Descriptive research is designed to describe the existing situation. It seeks to answer who, what, when, where and how questions (Zikmund, 2003). In this study, the researchers applied a survey technique by distributing questionnaires to gain feedback from respondents and to gain understanding about the perception of healthcare professionals on motivation and labour turnover at the hospital. According to Zikmund (2003), a survey technique can gather data or information from people by using a questionnaire. This survey, therefore, uses a questionnaire administered by the researchers to gather data from the respondents. The study population is the group of people who have the information that the researchers look for and from which conclusions can be acquired (Malhotra \& Birks, 2007). In this case, the study population was 225 healthcare professionals from the Dunkwa-On-Offin government hospital. From the total population, the minimum sample size required was 144 respondents. This was determined using the Sloven's formula; which states as 
follows: $\mathrm{n}=\frac{N}{1+N(e) 2}$ where $\mathrm{n}=$ sample size, $\mathrm{N}=$ accessible population and e = level of significance at 0.05 (Quarshie, Djimatey, \& Abakah-Anaman, 2018). However, the researchers sampled 165 respondents to make the study more representational and to take care of the non-retention rate of the questionnaires. The study employed a probability sampling technique, specifically, the simple random sampling technique to select the respondents. The simple random sampling was used because it gave room for each healthcare professional to be selected without any bias. The main instrument employed for the data collection was a structured closed-ended questionnaire.

The questionnaire was designed to provide specific responses aimed at addressing the research objective. Respondents were given the questionnaire with an explanation before responding to the items on the questionnaire. Likert scales were used in measuring the variables of interest, that is motivation and labour turnover. Thirty-four items on the questionnaire concerning motivation and employee turnover were administered to the respondents. Respondents were requested to tick the item that corresponds to their views on the Likert scale. The Likert scale ranges from $1=$ low agreement to $5=$ highest agreement. There are some reasons behind the selection of this method. First, it allows a large quantum of information to be solicited at a relatively low cost. Second, more accurate and precise responses are obtained because researchers bias can be avoided. To reduce the chances of getting inaccurate responses, attention was paid to the reliability and validity of the instrument used. Some steps were taken into consideration to ensure the validity and reliability of the study. Data were obtained from reliable sources which meant that a respondent must be a healthcare professional at the Dunkwa-On-Offin government hospital. The questionnaire was developed based on the literature reviewed. The questionnaire was pre-tested by the researchers to ensure it measured what it was supposed to and data were obtained during reasonable period. Results from the pre-test showed a Cronbach's Alpha of 0.82 in line with Pallant (2007) suggestions. To ensure strict compliance with ethical standards of research, written permission was duly sought from the hospital, which was duly granted before data were collected. The researchers introduced a clause in the introductory paragraph of the questionnaire assuring respondents of anonymity and confidentiality. Also, the time required for completing the questionnaire was mutually agreed between the respondents and the researchers.

\section{Results and Discussion}

\subsection{Demographic Information of Respondents}

In this study, respondents' background information was described in terms of sex, age range, highest educational level and length of service. The background was sought to enable the researchers to make a comparison among the respondents. The distribution of respondents' respective demographic information is captured in Table 1. The distribution of respondents' sex indicated that the majority (62.4\%) of respondents are females while the remaining $(37.6 \%)$ are males. This indicates that most of the healthcare professionals at the hospital are female-dominated. It can further be observed that out of the 165 respondents, the majority $(71.5 \%)$ are within the age group 20-29 years. This was followed by (25.5\%) of the respondents who are within the age group 30-39 years. The results imply that the Dunkwa-On-Offin government hospital is dominated by young adults who are aged between 20 and 29 years followed by primed-aged adults. Differences in the educational levels of workers may influence job satisfaction and willingness of employees to stay in their organizations. The table shows that $(58.2 \%)$ of the respondents hold a diploma. This was followed by $(15.2 \%)$ of the respondents who hold a certificate. Twenty-three per cent hold bachelor's degree and the rest (3.6\%) hold postgraduate certificates. The data shows that staff workforce at the hospital is to some extent dominated by diploma holders.

The study further examined the distribution of respondents' length of service at the hospital. This is important because the number of years staff have worked in the hospital is likely to influence their perception and level of motivation at the hospital. The data shows that majority (79.4\%) of the respondents have been working at the hospital for less than 5 years, whereas $(14.6 \%)$ of the respondents have been working at the hospital between 6-9 years.

Table-1. Background information of respondents.

\begin{tabular}{l|c|c}
\hline Background Information & Frequency & Per cent (\%) \\
\hline Sex & & 37.6 \\
\hline Male & 103 & 62.4 \\
\hline Female & 165 & 100 \\
\hline Total & 118 & 71.5 \\
\hline Age Range (years) & 42 & 25.5 \\
\hline 20-29 & 5 & 3.0 \\
\hline 30-39 & 165 & 100.0 \\
\hline 40-49 & & 58.2 \\
\hline Total & 96 & 15.2 \\
\hline Highest Educational Level & 25 & 23.0 \\
\hline Diploma & 38 & 3.6 \\
\hline Certificate & 6 & 100 \\
\hline Bachelor's Degree & 165 & \\
\hline Postgraduate Degree & & 79.4 \\
\hline Total & 131 & 14.6 \\
\hline Length of Service & 24 & 4.2 \\
\hline Less than 5 years & 7 & 1.8 \\
\hline $6-9$ years & 3 & 100.0 \\
\hline $10-14$ years & 165 & \\
\hline $15-19$ years & & \\
\hline Total & & \\
\hline Source: Field survey & & \\
\hline
\end{tabular}

Source: Field survey. 
Approximately two per cent of the respondents have worked within the hospital between 15-19 years. It is noted from the table that the percentage of respondents decreases with increasing years of length of service in the remaining categories. The implication is that the majority of healthcare professionals have worked within five years at the hospital. These categories of staff tend to leave the institution in the early years of appointment and may be attributed to the unmet expectation at the time of appointment.

\subsection{Motivation at the Dunkwa-on-offin Government Hospital}

From Table 2 , it is evident that most healthcare professionals agreed very highly that they feel glad when they help to save a patient's life in performing their duties (mean $=4.82 ; \mathrm{stdv} .=0.46$ ). The respondents expressed very high agreement levels on the issue that it is very important to them personally that they do their job very well $($ mean $=4.71 ;$ stdv. $=0.53)$. Most respondents agreed very highly that they view their job as a calling profession $($ mean $=4.49 ;$ stdv $=0.60)$. The respondents agreed very highly that they feel they are making a valuable contribution to the life of patients who patronise their services (mean $=4.41$; stdv. $=0.85$ ). The respondents in expressing their views on motivational factors at the hospital agreed very highly that the job provides them with the opportunity to develop their talent $($ mean $=4.16$; stdv. $=0.94)$ and further agreed very highly that their colleagues at the hospital are supportive $($ mean $=4.05$; stdv. $=0.84)$. The respondents agreed very highly that the job encourages self or personal development and creates a career path (mean $=4.01$; stdv. $=0.83)$. The respondents also agreed very highly that the hospital manager encourages teamwork (mean $=3.80$; stdv. $=0.92)$.

Analysis of data further shows that healthcare professionals feel committed to the Dunkwa-On-Offin government hospital $($ mean $=3.69 ; \mathrm{stdv} .=0.97)$ as illustrated in Table 3 . The respondents highly agreed that healthcare professionals feel free when working at the hospital (mean $=3.46$; stdv. $=1.13$ ). Most respondents highly agreed that the hospital manager discusses the performance of individual persons $($ mean $=3.43$; stdv. $=$ 1.05). Furthermore, the respondents highly agreed that the hospital manager motivates healthcare professionals to do a good job and duly recognizes their performance $($ mean $=3.35 ;$ stdv. $=1.18)$ and $($ mean $=3.32 ;$ stdv. $=1.15)$ respectively. Respondents highly agreed that their job security is assured at the hospital $(\mathrm{mean}=3.25$; stdv. $=$ 1.23). Also, the respondents highly agreed that the hospital provides the necessary resources to complete a task successfully (mean $=3.12$; stdv. $=1.16$ ). Again, respondents highly agreed that the Dunkwa-On-Offin government hospital pays fairly for the services rendered $($ mean $=2.82$; stdv. $=1.43)$ and highly agreed that healthcare professionals' needs at the hospital are taken into consideration $($ mean $=2.79 ;$ stdv. $=1.21$ ).

Table-2. Motivation at the dunkwa-on-offin government hospital.

\begin{tabular}{l|c|c|c}
\hline \multicolumn{1}{c}{ Table-2. Motivation at the dunkwa-on-offin government hospital. } \\
\hline Motivation & Mean & Std Dev & Interpretation \\
\hline Contentment & 4.82 & 0.46 & very high \\
\hline Service importance & 4.71 & 0.53 & very high \\
\hline Noble profession & 4.49 & 0.60 & very high \\
\hline Valuable contribution & 4.41 & 0.85 & very high \\
\hline Talent development & 4.16 & 0.94 & very high \\
\hline Supportive colleagues & 4.05 & 0.84 & very high \\
\hline Career path & 4.01 & 0.83 & very high \\
\hline Teamwork & 3.80 & 0.92 & very high \\
\hline Commitment & 3.69 & 0.97 & high \\
\hline Safe and secure & 3.46 & 1.13 & high \\
\hline Performance discussion & 3.43 & 1.05 & high \\
\hline Encouragement & 3.35 & 1.18 & high \\
\hline Recognition & 3.32 & 1.15 & high \\
\hline Job security assurance & 3.25 & 1.23 & high \\
\hline Resources provision & 3.12 & 1.16 & high \\
\hline Fair payment & 2.82 & 1.43 & high \\
\hline Consideration of staff needs & 2.79 & 1.21 & high \\
\hline Key: Mean range interpretation of the level of
\end{tabular}

Key: Mean range interpretation of the level of motivation.

1 - 1.25 - low; 1.26 - 2.5 - moderate; 2.56 - 3.75 - high; 3.76 - 5 - very high.

\subsection{Motivation Impact on Labour Turnover at the Dunkwa-on-Offin Government Hospital}

The multiple regression analysis was employed to examine the impact of motivation on labour turnover at the Dunkwa-On-Offin government hospital. The requirements of multiple regression were followed before establishing the impact. The results of the test can be observed in Tables 3, 4 and 5. From Table 4, the multiple regression analysis (model summary) indicates that the independent variables met the entry requirement for the model. The $R$ (0.406) shows a medium positive correlation between the predictive variables (working environment, work content, recognition, payment and promotion) and the dependent variable (labour turnover). The adjusted $R$-square value reveals that about $14.4 \%$ of the variance in labour turnover is explained by the motivational factors at the hospital. This implies that the remaining $85.6 \%$ of labour turnover at the hospital is explained by other variables apart from these motivational factors.

Table-3. Model summary.

\begin{tabular}{c|c|c|c|c}
\hline Model & $\mathbf{R}$ & R Square & Adjusted R Square & Std. Error of the Estimate \\
\hline 1 & $0.406^{\text {a }}$ & 0.165 & 0.144 & 6.5425 \\
\hline \multicolumn{2}{l}{ Note: a Predictors: (Constant), working environment, work content, recognition, payment and promotion. }
\end{tabular}

Note: a Predictors: (Constant), working environment, work content, recognition, payment and promotion.

b Dependent variable: Labour turnover.

In the ANOVA (F-test) in Table 4, it can be seen simultaneously that the independent variables (working environment, work content, recognition, payment and promotion) have a significant impact on labour turnover as shown from the value of Sig. $0.000<\alpha=0.05$. Hence it could be concluded that the variation in the dependent 
variable can be explained by the linear regression model specified. This shows that there is a linear relationship between the dependent variable and the predictor variables.

Table-4. ANOVA(b)

\begin{tabular}{c|c|c|c|c|c}
\hline Model & Sum of Squares & df & Mean Square & F & Sig. \\
\hline Regression & 1348.514 & 4 & 337.129 & 7.876 & $.000(\mathrm{a})$ \\
\hline Residual & 6848.662 & 160 & 42.804 & & \\
\hline Total & 8197.176 & 164 & & & \\
\hline
\end{tabular}

Note: a Predictors: (Constant), working environment, work content, recognition, payment and promotion.

b Dependent variable: Labour turnover.

Beta $(\beta)$ or standardized coefficient figures as presented in Table 5 were used to demonstrate the magnitude of motivation impact on labour turnover at the Dunkwa-On-Offin government hospital. The constant value of 44.16 indicates that if the independent variables are assumed to be constant, then the mean of the labour turnover at the government hospital is 44.16. From Table 5, work content and payment and promotion do not have a significant impact on labour turnover at the Dunkwa-On-Offin government hospital. Based on the coefficients results in Table 5 , it can be observed that recognition of employees has a significant negative impact on labour turnover. This can be seen from the value of sig. $=0.004<0.05 ; \mathrm{t}=-2.925 ; \beta=-0.476$. The $\mathrm{p}$-value of 0.004 associated with recognition shows that its contribution to labour turnover is significant. This further implies that a point increase in employee recognition leads to about 0.476 decreases in labour turnover at the Dunkwa-On-Offin government hospital. The finding is consistent with Bhatt (2015) study which reported that employee knowledge, skills and competencies are very important for organizations. For this reason, managers need to be able to map and retain highly skilled employees and always remind them how valuable they are to the organization. Similarly, Selden and Sowa (2015) study also reported that for organizations to improve on employee retention, they should invest more time and resources on developing employees as future leaders and cultivating a positive working environment.

It can further be observed from Table 5 that the working environment has a significant negative impact on labour turnover. This can be seen from the value of sig. $=0.015<0.05 ; \mathrm{t}=-2.468 ; \beta=-0.319$. The $\mathrm{p}$-value of 0.015 associated with working environment shows that its contribution to labour turnover is significant. This implies that a point increase in working environment leads to about 0.319 decreases in labour turnover at the Dunkwa-OnOffin government hospital. This finding corroborates Wells and Thelen (2002) study which documents that a positive work environment is believed to make employees feel good about coming to work and provide the necessary motivation to sustain them throughout the day. This observation was further echoed by Heneman (2007) who intimated that organizations which offer suitable levels of privacy and sound controls at the workplace improves the levels of motivation and commitment in employees. This also has the ability to satisfy and retain employees. Heneman further alludes to the fact that one of the most crucial elements of any organizations total reward strategy is having a positive work environment.

Table-5. Coefficient(a)

\begin{tabular}{|c|c|c|c|c|c|}
\hline \multirow[b]{2}{*}{ Model } & \multicolumn{2}{|c|}{ Unstandardized Coefficients } & \multirow{2}{*}{$\begin{array}{c}\text { Standardized Coefficients } \\
\operatorname{Beta}(\boldsymbol{\beta})\end{array}$} & \multirow[b]{2}{*}{$\mathbf{t}$} & \multirow[b]{2}{*}{ Sig. } \\
\hline & B & Std. Error & & & \\
\hline (Constant) & 44.162 & 4.745 & & 9.307 & .000 \\
\hline Work Content & 0.281 & 0.197 & 0.123 & 1.424 & .156 \\
\hline Payment and Promotion & 0.025 & 0.163 & 0.016 & .153 & .878 \\
\hline Working Environment & -0.319 & 0.129 & -0.247 & -2.468 & .015 \\
\hline Recognition & -0.476 & 0.163 & -0.289 & -2.925 & .004 \\
\hline
\end{tabular}

Note: a Predictors: (Constant), working environment, work content, recognition, payment and promotion

b Dependent variable: Labour turnover.

\section{Conclusions and Recommendations}

Healthcare professionals at the Dunkwa-On-Offin government hospital perceived highly that motivation is very important for enhancing retention, improving staff performance, effectiveness and efficiency. However, a section of healthcare professionals perceived that motivation at the hospital is quite inadequate. Which implies that the nature of motivational issues at the hospital, if not addressed properly, could affect staff retention. This situation can adversely affect staff performance, effectiveness and efficiency and eventually increase staff turnover at the hospital. The study also discovered a significant relationship between recognition, working environment and labour turnover at the Dunkwa-On-Offin government hospital. This finding implies that an improvement in employee recognition and working environment will promote staff retention and reduce the challenges of high staff turnover at the hospital. This further means that an improvement in these factors at the hospital will lead to the desired increase in staff retention. The study recommends that some policy measures could be adopted by hospital management to ensure that best motivational issues are followed to employ and retain competent staff. Staff who can help the Dunkwa-On-Offin government hospital to achieve its strategic goals. Management of the hospital should maintain credibility in the implementation of the various motivational practices to enhance staff satisfaction. These may include ensuring fairness in promotion and opportunities for career development. This can be achieved by sensitizing supervisors to maintain fairness in staff selection for specific training and career development programmes as well as issues on promotion. Hospital management should involve their employees when they make decisions. Once staff are actively involved in decision-making, they will be willing to exert more effort because they were part of the decision. 
References

Adjei-Appiah, S. A. (2008). Organizational climate and turnover in the health sector: the Case of the Korle-Bu Teaching Hospital in Ghana. A Thesis Presented to the University of Waterfloo for Degree of Master in Psychology, Ontario, Canada.

Agyei-Ohemeng, J., \& Sedegah, D. (2018). Labour turnover in selected hotels in the Sunyani Municipality. Journal of Hospitality Tourism, 5(3), $1-13$.

Agyemang, C. B., Nyanyofio, J. G., \& Gyamfi, G. D. (2014). Job stress, sector of work, and shift-work pattern as correlates of worker health and safety: A study of a manufacturing company in Ghana. International Journal of Business and Management, 9(7), 59-69.Available at: https://doi.org/10.5539/ijbm.v9n7p59.

Aksu, A. (2004). Turnover costs: research among five-star hotels in the city of Antalya, Turkey. Tourism Analysis, 9(3), 207-217.Available at: https://doi.org/10.3727/1083542042781230.

Amedzo, V. (2007). Industrial psychology. Accra: Adonai Publications.

Arkoh, A. (2004). The recruitment and retention of healthcare workers, 2004-2005 Accra: Ghana Publishing House.

Bhatt, K. (2015). Developing and sustaining intellectual assets of an organization through talent management: An analytical study of private sector insurance companies of Gujarat state.

Bültmann, U., Huibers, M. J., van Amelsvoort, L. P., Kant, I., Kasl, S. V., \& Swaen, G. M. (2005). Psychological distress, fatigue and longterm sickness absence: prospective results from the Maastricht Cohort Study. Journal of Occupational and Environmental Medicine, 47(9), 941-947.Available at: https://doi.org/10.1097/01.jom.0000172865.07397.9a.

Carbery, R., Garavan, T. N., O'Brien, F., \& McDonnell, J. (2003). Predicting hotel managers' turnover cognitions. Journal of Managerial Psychology, 18(7), 649-679.Available at: https://doi.org/10.1108/02683940310502377.

Chiboiwa, M. W., Samuel, M. O., \& Chipunza, C. (2010). An examination of employee retention strategy in a private organisation in Zimbabwe. African Journal of Business Management, 4(10), 2103-2109.

Cooper, C. L., \& Marshall, J. (1978). Sources of managerial and white- collar stress. In C.L. Cooper \&R. Payne (Eds), stress at work (pp. $81-$ 106). Chichester: Wiley.

Cooper., G. L., Dewe, P. J., \& O’Driscoll, M. P. (2001). Organizational stress: A review and critique of theory. California: Sage.

Galinsky, E., Kim, S. S., \& Bond, J. T. (2001). Feeling overworked: When work becomes too much. New York, Family and Work Institute.

Glazer, S., \& Beehr, T. A. (2005). Consistency of implications of three role stressors across four countries. Journal of Organizational Behavior: The International Journal of Industrial, Occupational and Organizational Psychology and Behavior, 26(5), 467-487.Available at: https://doi.org/10.1002/job.326.

Hay Group. (2001). The retention dilemma: Why productive workers leave. Hay London: Insight. Hay Group Inc.

Heneman, R. (2007). Implementing total reward strategies. New York: Society for Human Resource Management Press.

Herzberg, F. W., Mausner, B., \& Sayderman. (1957). The motivation to work. New York: Wiley.

Hinkin, T. R., \& Tracey, J. B. (2000). The cost of turnover. Cornell Hotel and Restaurant Administration Quarterly, 58(1), $14-21$.

Hu, Y., Wang, D., Xu, G., \& Xu, P. (2014). The relationship between work stress and mental health in medical workers in East China. Social Behavior and Personality: An International Journal, 42(2), 237-244.Available at: https://doi.org/10.2224/sbp.2014.42.2.237.

Hytter, A. (2008). Dark side leaders, work environment and employee health. Småland: Växjö University Press.

Ivancevich, J. M., \& Ganster, D. C. (1987). Job stress from theory to suggestion. London: The Haworth Press.

Jex, S. M. (1998). Stress and job performance: Theory, research, and implications for managerial practice. Thousand Oaks: Sage Publications.

Johnson, K. (1981). Toward an understanding of labour turnover? Service Industries Review, 1(1), 4- 17.

Kaak, S. R., Field, H. S., Giles, W. F., \& Norris, D. R. (1998). The weighted application blank. New York: Sage.

Kahn., R., Wolfe, R., Quinn, R., \& Snoek, J. (1964). Organizational stress: Studies in role conflict and ambiguity. New York: Wiley.

Kohn, L. (1996). Pay satisfaction and organizational outcomes. Personnel Psychology, 58(3), 613-640.Available at: https://doi.org/10.1111/j.1744-6570.2005.00245.x.

Kosi, I., Sulemana, I., Boateng, J. S., \& Mensah, R. (2015). Teacher motivation and job satisfaction on intention to quit: An empirical study in public second cycle schools in Tamale metropolis, Ghana. International Journal of Scientific and Research Publications, 5(5), 1-8.

Lashley, C. (2000). Hospitality retail management: A unit manager's guide. Oxford: Butterworth Heinemann.

Law, J., Pearce, P. L., \& Woods, B. A. (1995). Stress and coping in tourist attraction employees. Tourism Management, 16(4), 277284.Available at: https://doi.org/10.1016/0261-5177(95)00017-i.

Lawler, I. E. E. (1996). From the ground up: Six principles for building the New Logic Corporation. San Francisco: Jossey-Bass Publishers.

Levi, L. (2002). The European Commission's Guidance on work-related stress: From words to action. TUTB newsletter, 19(20), 12-17.

Malhotra, N., \& Birks, D. (2007). Marketing research: An applied approach. London: Financial Times.

March, J. G., \& Simon, H. A. (1958). Organizations. New York: John Wiley \& Sons.

McBey, K., \& Karakowsky, L. (2001). Examining sources of influence on employee turnover in the part-time work context. Career Development International, 6(1), 39-47.

Miller, N. G., Erickson, A., \& Yust, B. L. (2001). Sense of place in the workplace: The relationship between personal objects and job satisfaction and motivation. Journal of Interior Design, 27(1), 35-44.Available at: https://doi.org/10.1111/j.19391668.2001.tboo364.x.

Ministry of Health. (2002). Internal report on human resources. Accra: Ministry of Health, Accra.

Ministry of Health. (2016). Annual DMS report. Accra: Ministry of Health (MoH), Accra.

Mobley, W. H. (1977). Intermediate linkages in the relationship between job satisfaction and employee turnover. Journal of Applied Psychology, 62(2), 237-240.Available at: https://doi.org/10.1037/002 1-9010.62.2.237.

Mobley, W. H. (1982). Employee turnover: Causes, consequences, and control. New York: Addision-Wesley Publishing.

Morrow, P. C., McElroy, J. C., Laczniak, K. S., \& Fenton, J. B. (1999). Using absenteeism and performance to predict employee turnover: Early detection through company records. Journal of Vocational Behavior, 55(3), 358-374.Available at: https://doi.org/10.1006/jvbe.1999.1687.

Noe, R. A., Hollenbeck, J. R., Gerhart, B., \& Wright, P. M. (2003). Fundamentals of human resource management. New York: McGraw-Hill.

Nowrouzi, B., Lightfoot, N., Larivière, M., Carter, L., Rukholm, E., Schinke, R., \& Belanger-Gardner, D. (2015). Occupational stress management and burnout interventions in nursing and their implications for healthy work environments: A literature review. Workplace Health E Safety, 63(7), 308-315.Available at: https://doi.org/10.1177/2165079915576931.

Numerof, R. E., Abrams, M. N., \& Shank, G. S. (2002). Retention of highly productive personnel now at crisis proportions. Health Care Strategic Management, 20(3), 10-12.

Pallant, J. (2007). SPSS survival manual: A step by step guide to data analysis using SPSS version 15. New York: McGraw-Hill.

Pisljar, T., Lippe, T. V. D., \& Dulk, L. D. (2011). Health among hospital employees in Europe: A cross-national study of the impact of work stress and work control. Social Science \& Medicine, 72(6), 899-906.Available at: https://doi.org/10.1016/j.socscimed.2010.12.017.

Price, J. L. (1977). The study of turnover. Iowa: State University Press.

Quarshie, M. A., Djimatey, R., \& Abakah-Anaman, A. (2018). Service quality delivery of rural banks: Perception of customers in emerging economies. Asian Business Research Journal, 3(1), 33-40.Available at: https://doi.org/10.20448/journal.5 18.2018.31.33.40.

Ramlall, S. (2003). Organizational application managing employee retention as a strategy for increasing organizational competitiveness. Applied H.R.M. Research, 8(2), 63-72.

Rowley, G., \& Purcell, K. (2001). As cooks go, she went: Is labour churn inevitable? International Journal of Hospitality Management, 20(2), 163-185.Available at: https://doi.org/10.1016/s0278-4319(00)00050-5.

Sam, F., Effah, B., \& Osei-Owusu, B. (2014). Exploring issues of teacher retention and attrition in Ghana: A case study of Public Senior High Schools in Kwabre East district of Ashanti region-Ghana. Journal of Education and Practice, 5, 83-89.

Saratoga Institute and Kepner-Tregoe, I. (1999). Turnover costing model. New York: Saratoga Institute.

Selden, S. C., \& Sowa, J. E. (2015). Voluntary turnover in nonprofit human service organizations: The impact of high performance work practices. Human Service Organizations: Management, Leadership \& Governance, 39(3), 182-207.Available at: https://doi.org/10.1080/23303131.2015.1031416. 
Shields, M. A., \& Ward, M. (2001). Improving nurse retention in the National Health Service in England: The impact of job satisfaction on intentions to quit. Journal of Health Economics, 20(5), 677-701.Available at: https://doi.org/10.1016/s0167-6296(01)00092-3.

Sigler, R. T. (1988). Role conflict for adult probation and parole officers: Fact or myth. Journal of Criminal Justice, 16(2), 121-129. Stranks, J. (2005). Stress at work: Management and prevention. Oxford: Elsevier Butterworth Heinemann.

Wells, M., \& Thelen, L. (2002). What does your workspace say about you? The influence of personality, status, and workspace on personalization. Environment and Behavior, 34(3), 300-321.Available at: https://doi.org/10.1177/0013916502034003002.

Wright, T. A. (1993). Correctional employee turnover: A longitudinal study. Journal of Criminal Justice, 21(2), 131-142.Available at: https://doi.org/10.1016/0047-2352(93)90071-t.

Zeytinoglu, I. U., \& Denton, M. (2006). Satisfied workers, retained workers: Effects of work and work environment on homecare workers' job satisfaction, stress, physical health, and retention. Ontario: McMaster University.

Zikmund, W. G. (2003). Business research method (7th ed.). India: Cengage Learning.

Zohar, D. (1994). Analysis of job stress profile in the profile. International Journal Hospitality Management, 13(3), 219 - 231. 